\title{
REPÚBLICA, DEMOCRACIA E AUTONOMIA: ENTRE PILARES \\ E LÁPIDES
}

Luiz Edson Fachin ${ }^{1}$

Christine Oliveira Peter da Silva

\section{Introdução: homenagem ao PPGD da USP, ensejo para reflexão}

Era uma certa primavera. A barbárie e a crise dos anos anteriores, com a deterioração dos princípios basilares da noção social e institucional de liberdade, democracia e república, não intimidaram florescessem constituintes a prescreverem democracia e república complexas, tolerantes e sustentáveis para o Brasil do futuro. Resposta e compromisso, as normas da Constituição de 1988 emergem assim como sinais intensos desse fenômeno.

A educação, a cultura e a universidade como direitos fundamentais e garantias institucionais do Estado Democrático de Direito ganharam seção e capítulos próprios, indicativo da esperança depositada em sua força motriz para impulsionar o projeto que ali estava posto.

Uma resposta ao Estado de Direito democrático e à sociedade que fundou a Constituição de 1988 intentou ofertar. Marco indelével da emancipação cidadã do povo brasileiro, não apenas sob o ponto de vista de sua generosa previsão de direitos fundamentais políticos, mas também pelo cuidado e atenção que dispensou para a Educação e para a Universidade, o desenho normativo vinculante se projetou numa sociedade livre, justa e solidária, a fim de erradicar a pobreza e a marginalização e reduzir as desigualdades sociais e regionais, e promover o bem de todos, sem preconceitos de origem, raça, sexo, cor, idade e quaisquer outras formas de discriminação.

Não havia, entretanto, como premeditar os desafios e os paradoxos que nasceram juntos com a Constituição Cidadã. O tempo era de rompimento, de comemoração pelo fim dos tempos obscuros e obtusos já idos, mas o porvir era possível.

Contudo, depois de três décadas transcorridas, agora uma densa atmosfera outonal paira nesse tempo com ares de ocaso. O movimento oscilatório traduz perdas e perdas.

\footnotetext{
1 Ministro do Supremo Tribunal Federal; Alma Mater: Universidade Federal do Paraná (UFPR); Doutor e Mestre em Direito pela PUC-SP.

2 Doutora e Mestre em Direito, Estado e Constituição pela UnB; Professora Associada do Mestrado e Doutorado em Direito das Relações Internacionais do Centro Universitário de Brasília (UniCeub); Assessora de Ministro do Supremo Tribunal Federal.
} 
As crises decorrentes da emergência sanitária global agravaram fenômenos trágicos da própria tensão planetária então vivida; o colapso humanitário se traduzia em deslocamentos populacionais forçados, perseguições xenófobas, guerras e conflitos étnicos, dizimação de etnias indígenas, não acolhimento de imigrantes, refugiados ao desabrigo, exclusão social, genocídios, crimes contra a humanidade, entre outras atrocidades. Ainda mais cruéis se tornaram essas desumanidades.

O campo das instituições, mormente daquelas voltadas à educação superior, na pesquisa, na extensão e no ensino, tornou-se também terreno ainda mais assolado por descasos, recentemente adicionadas arbitrariedades e parvoíces.

Instaurada a crise, em todos os seus âmbitos, é preciso um esforço institucional, republicano e democrático para reconstruir o sentido, abstrato e concreto, de Universidade. O ponto de partida dessa reconstrução normativa deve ser a própria Constituição da República. O texto do art. 207 da Constituição de 1988 trata de "autonomia didático-científica, administrativa e de gestão financeira e patrimonial".

Integrados nesse espírito, e no intuito de colaborar com a prestigiosa iniciativa de comemorar os 50 anos do Programa de Pós-Graduação da Faculdade de Direito da Universidade de São Paulo, apresentamos aqui a nossa celebração, com reflexões acadêmicas, marcas indeléveis e, perenemente, visíveis, dessa pioneira e bemsucedida história institucional.

\section{Universidade \& Constituição: uma agenda}

Constituição e Universidade se encontram, no caminho da nação, na formação dos sujeitos e protagonistas de sua própria história. As crises enfrentadas pela Constituição são também sentidas pela Universidade, e vice-versa, pois não há como deixar de reconhecer que a formação do povo, em todas as suas mais amplas perspectivas, é espelho, portanto reflexo, da nação constituída.

Pensar por problemas, mover-se por entre dúvidas, testar hipóteses numa dialética problematizadora, dialogar com o pensamento divergente, intercambiar ideias numa cultura de fundamentação racional e sistemática, são elementos que integram o campo das premissas na investigação científica adequada, especialmente na pós-graduação em Direito. Nada obstante, quando as reais mazelas são eclipsadas pela intelligentsia ao servir à lógica da exclusão, da autocracia, das descontinuidades democráticas, a quem serve esse mainstream?

Desafios a granel põem no palco temas que suscitam atenção nessa perspectiva, quiçá de faltas e ausências: ações afirmativas, oportunidade real a grupos 
vulnerabilizados, tais como negros ${ }^{3}$ (pretos e pardos), indígenas, quilombolas, pessoas com deficiência, pessoas transgênero, com hipossuficiência econômica; respeito à alteridade; justiça substantiva, dentre outros, são provocações entregues à sociedade brasileira pelo constituinte de 1988, tão complexas e densas, que impõem a vinculatividade por exigência de comprometimento com a eficácia das normas constitucionais.

Cumpre refletir sobre soterramentos e garimpagens hermenêuticas. A Constituição não é norma que nasce uma única vez, é texto normativo que se reconstitui e renasce nas práticas institucionais, sociais e políticas da nação que a constitui. A nação, como coletivo de um povo integral, tem na sua Constituição o projeto para seguir o seu caminho, não livre de encruzilhadas, armadilhas, sobressaltos e paradoxos.

O presente trabalho é fruto do pensar junto de duas gerações de professores, uma que acompanhou o processo constituinte de 1988, e a outra que ouviu e edificou-se, com entusiasmo e esperança, sobre a força e potência do compromisso constitucional forjado naqueles tempos.

A questão aqui posta para reflexão são as necessárias conexões entre os princípios constitucionais democrático e republicano, sustentáculos da Constituição de 1988, com a garantia institucional da autonomia universitária. Se democracia e república constituem e são constituídas pela Constituição Cidadã, as universidades também devem ser fontes e espelhos da cidadania democrática e republicana.

Dois trabalhos acadêmicos ajudaram a construir a narrativa e o discurso do presente texto, em um profícuo diálogo com a história e a influência portuguesas no cerne da questão aqui posta: "A ideia de universidade e a universidade de ideias", ${ }^{4}$ publicado em 1989, e "A universidade no século XXI: para uma reforma democrática e emancipatória da universidade", 5 cuja primeira edição foi publicada no Brasil em 2004, ambas de autoria do professor Boaventura de Sousa Santos.

O diálogo narrativo a ser encontrado no presente trabalho também prestigiará as posições institucionais ocupadas pelos interlocutores da fala, de forma que o 'magistério jurisprudencial', ${ }^{6}$ do Supremo Tribunal Federal, bem como excertos doutrinários, frutos de reflexões acadêmicas, serão abundantes em citações diretas.

\footnotetext{
"Contra a alienação a que é submetido o sujeito negro no mundo", ver: SANTOS, Richard. Maioria minorizada: um dispositivo da racionalidade. Rio de Janeiro: Telha, 2020. p. 39.

4 SANTOS, Boaventura de Sousa. Da ideia de Universidade à Universidade de ideias. Revista Crítica de Ciências Sociais, v. 27, n. 28, 1989, p. 11-62.

5 SANTOS, Boaventura de Sousa. A universidade no século XXI: para uma reforma democrática e emancipatória da Universidade. $3^{\mathrm{a}}$ ed. São Paulo: Editora Cortez, 2010.

6 Magistério jurisprudencial é expressão forjada e presentificada, principalmente, na atuação jurisdicional magistral do Ministro Celso de Mello, a quem singelamente homenageamos pelas contribuições inestimáveis à Constituição e à nação brasileira.
} 
Múltiplas são as crises enfrentadas pelas Universidades, nas últimas décadas, não apenas no Brasil, mas em todo o mundo. Conforme anota Boaventura de Sousa Santos:

Nos últimos vinte anos a universidade tem-se vindo a confrontar com a progressiva erosão das dicotomias que sustentam a sua estabilidade e a sua especificidade institucional: alta cultura/cultura popular; educação/ trabalho; teoria/prática. Os sintomas de tal erosão têm-se manifestado como crise de hegemonia crise de legitimidade e crise institucional. As medidas que têm sido tomadas para as superar têm sido pouco eficazes. É necessário repensar inovadora e radicalmente a ideia de universidade para esta se possa transformar numa universidade de ideias. ${ }^{7}$

Certamente, não é pretensão do presente trabalho apresentar dogmas ou percepções definitivas, nem pontos de vista indenes de contestação, mas, sim, contribuir, reflexivamente, para o que o professor Boaventura de Sousa Santos chama de 'conhecimento pluriversitário', ${ }^{8}$ ou seja, "um conhecimento contextual na medida em que o princípio organizador da sua produção é a aplicação que lhe pode ser dada". 9

\section{Universidade \& Democracia ${ }^{10}$}

Homenageando José Saramago, que, em 2005, numa conferência na Universidade Complutense de Madrid, chamou a atenção para a necessária distinção entre 'educação' e 'instrução', dá-se início aqui às reflexões sobre a missão das universidades nas democracias contemporâneas.

Não há muitas controvérsias diante do fato de que um dos inevitáveis desafios das democracias contemporâneas é a disponibilização de mecanismos capazes de articular a garantia de participação política do povo, considerado em sua

\footnotetext{
SANTOS, Boaventura de Sousa. Da ideia de Universidade à Universidade de ideias. Revista Crítica de Ciências Sociais, v. 27, n. 28, 1989, p. 11.

8 Segundo o professor: “(...) É um conhecimento transdisciplinar que, pela sua própria contextualização, obriga a um diálogo ou confronto com outros tipos de conhecimento, o que o torna internamente mais heterogêneo e mais adequado a ser produzido em sistemas abertos menos perenes e de organização menos rígida e hierárquica. (...) A sociedade deixa de ser um objeto das interpelações da ciência para ser ela própria sujeita de interpelações à ciência." Vide: SANTOS, Boaventura de Sousa. A universidade no século XXI: para uma reforma democrática e emancipatória da Universidade. 3. ed. São Paulo: Editora Cortez, 2010, p. 42.

9 SANTOS, Boaventura de Sousa. A universidade no século XXI: para uma reforma democrática e emancipatória da Universidade. 3. ed. São Paulo: Editora Cortez, 2010, p. 42.

10 Aqui é preciso registrar a obra homônima ao tópico: SARAMAGO, José. Democracia e Universidade. Belém/PA: Editora UFPA - Fundação José Saramago, 2013. Esta obra é composta por duas conferências: a primeira, que dá título ao livro, aconteceu na Universidade Complutense de Madrid, em 2005; a segunda, intitulada 'Verdade e ilusão democrática', foi lida em Santiago do Chile, em 2003.
} 
unidade numérica de contingente eleitoral, com a garantia de cidadania participativa, que apresenta o povo como sujeito ativo e, pluralmente, atuante nos tempos e nos espaços da democracia. ${ }^{11}$

A ideia de democracia não mais pode ser identificada como um mero regime político associado à forma de governo, pois que, cada vez mais, a democracia vem se apresentando como uma forma geral da existência social:12 como uma forma sociopolítica definida pelo princípio da isonomia e da isegoria; ${ }^{13}$ como uma forma política; ${ }^{14}$ como uma forma de criação de direitos $;{ }^{15}$ e como uma forma de participação popular. ${ }^{16}$

Não se pode perder de vista que, em todas as suas versões - representativa, deliberativa ou participativa -, a democracia aponta para uma progressiva e irreversível emancipação dos sujeitos que se materializam como atores políticos de um processo histórico de cidadania legitimadora. ${ }^{17}$

A democracia, nesse sentido, também se apresenta como uma consciência do agir com o outro, para o outro e em prol do outro, a qual deve substituir a cultura em

$11 \quad$ FACHIN, Luiz Edson; SILVA, Christine Peter da. Democracia representativa no Brasil: breves reflexões sobre a participação do povo como sujeito político. In: PEREIRA Erick Wilson (org.). Reforma política: Brasil república: em homenagem ao Ministro Celso de Mello. Brasília: OAB, Conselho Federal, 2017, p. 115-130.

12 Por meio da qual "uma sociedade, dividida internamente em classes, estabelece as relações sociais, os valores, os símbolos e o poder político a partir da determinação do justo e do injusto, do legal e do e do ilegal, do legítimo e do ilegítimo, do verdadeiro e do falso, do bom e do mau, do possível e do necessário, da liberdade e da coerção;" CHAUÍ, Marilena. Escritos sobre a universidade. São Paulo: Editora UNESP, 2001, p. 10.

13 Isonomia é definida pela professora Marilena Chauí como igualdade dos cidadãos perante a lei, e isegoria como o direito de todos para expor em público suas opiniões, vê-las discutidas, aceitas ou recusadas, no espaço público. CHAUÍ, Marilena. Escritos sobre a universidade. São Paulo: Editora UNESP, 2001, p. 10.

14 Aqui política quer significar uma forma, que ao contrário de todas as outras considera legítimo o conflito para que as mediações institucionais possam exprimirem-se. "A democracia não é o regime do consenso, mas do trabalho dos e sobre os conflitos. Donde uma outra dificuldade democrática nas sociedades de classe: como operar com os conflitos quanto estes possuem a forma da contradição e não a de mera oposição? CHAUÍ, Marilena. Escritos sobre a universidade. São Paulo: Editora UNESP, 2001, p. 10-11.

15 No particular anota a professora Marilena Chauí: “(...) a democracia surge como o único regime político realmente aberto às mudanças temporais, uma vez que faz surgir o novo como parte de sua existência e, consequentemente, a temporalidade como constitutiva do seu modo de ser." CHAUÍ, Marilena. Escritos sobre a universidade. São Paulo: Editora UNESP, 2001, p. 11.

16 Anota a professora Marilena Chauí “(...) a marca da democracia moderna, permitindo sua passagem de democracia liberal a democracia social, encontra-se no fato de que somente as classes populares e os excluídos (as "minorias") sentem a exigência de reivindicar direitos e criar novos direitos. CHAUÍ, Marilena. Escritos sobre a universidade. São Paulo: Editora UNESP, 2001, p. 11.

17 FACHIN, Luiz Edson; SILVA, Christine Peter da. Democracia representativa no Brasil: breves reflexões sobre a participação do povo como sujeito político. In: PEREIRA, Erick Wilson (org.). Reforma política: Brasil república: em homenagem ao Ministro Celso de Mello. Brasília: OAB, Conselho Federal, 2017, p. 115-130. 
que os sujeitos não sabem interagir uns com os outros, nem respeitar e considerar uns aos outros como iguais. ${ }^{18}$

Para que a democracia brasileira se consolide, em substância, como expressão máxima da coletividade do povo brasileiro, é preciso suplantar velhos modelos mais solipsistas, para deixar nascerem e fortalecerem-se modelos em que a vida social e coletiva, embalada por valores comunitários, permitam que intersubjetividades solidarizadas por objetivos verdadeiramente comuns, dentre os quais, liberdade, responsabilidade e igualdade, constituam-se como elementos centrais informadores também das universidades.

Evidenciando tal objetivo, escolhemos a Arguição de Descumprimento de Preceito Fundamental n. 548, julgada pelo Plenário do Supremo Tribunal Federal, em sede medida cautelar, em outubro de 2018 e, no seu mérito, em maio de 2020, como referência jurisprudencial para provocar as reflexões sobre a relação entre universidade e democracia.

A notícia sobre esta ação está assim registrada no sítio eletrônico do Supremo Tribunal Federal:

Por unanimidade, o Plenário do Supremo Tribunal Federal (STF), em sessão virtual, julgou procedente a Arguição de Descumprimento de Preceito Fundamental (ADPF) 548, para declarar nulas decisões da Justiça Eleitoral em cinco estados que impuseram a interrupção de manifestações públicas de apreço ou reprovação a candidatos em ambiente virtual ou físico de universidades às vésperas do segundo turno da eleição de 2018. As decisões envolviam busca e apreensão de materiais de campanha eleitoral em universidades e associações de docentes e proibição de aulas com temática eleitoral e de reuniões e assembleias de natureza política.

No julgamento do mérito da ADPF, os ministros confirmaram a medida cautelar, concedida pela ministra Cármen Lúcia e referendada pelo Plenário em outubro de 2018. Em seu voto, a relatora disse que as decisões judiciais violaram o princípio constitucional da autonomia universitária e são contrárias à dignidade da pessoa, à autonomia dos espaços de ensinar e aprender, ao espaço social e político e ao princípio democrático. "Sendo práticas determinadas por agentes estatais (juizes ou policiais) são mais inaceitáveis. Pensamento único é para ditadores. Verdade absoluta é para tiranos. A democracia é plural em sua essência. E é

18 BITTAR, Eduardo C.B., Democracia, Justiça e Direitos Humanos - estudos de teoria crítica e filosofia do direito. São Paulo: Saraiva, 2011, p. 49-51. 
esse princípio que assegura a igualdade de direitos na diversidade dos indivíduos. ${ }^{19}$

Por ocasião desse julgamento, restou lembrado que a liberdade de pensamento como um pilar da democracia, bem como a jurisprudência consolidada da Corte sobre liberdade de expressão e pensamento como posições preferenciais no Estado Democrático de Direito, expressou:

A universidade e as instituições de ensino são expressão máxima dessa garantia. $\mathrm{O}$ ingresso no espaço público está condicionado à educação participativa, inclusiva, plural e democrática que as instituições de ensino promovem. É na educação que o livre debate de ideias, o intercâmbio de visões de mundo e o contraste de opinião têm livre curso. Somente esse ambiente prepara as pessoas para reconhecerem o melhor governo, a melhor decisão, a melhor lei e o melhor argumento. Sem educação não há cidadania. Sem liberdade de ensino e de pensamento não há democracia.

Não há ofensa à igualdade eleitoral quando as manifestações críticas às ideias dos candidatos são expressas na universidade ou em qualquer outro espaço. $\mathrm{O}$ debate eleitoral, indispensável para escolha informada sobre o destino do país, pressupõe o confronto, o convencimento e o proselitismo, às vezes ríspido, que os assuntos políticos despertam.

A propaganda eleitoral, por sua vez, pressupõe que a mensagem divulgada por candidato ou seu apoiador seja recebida passivamente pelo seu destinatário. Conquanto inserta no mesmo direito à liberdade de expressão, a propaganda distingue-se substancialmente do debate, do diálogo e da troca de impressões. Por isso, a pretexto de regular a propaganda não se pode jamais impedir o diálogo e o debate de ideias.

Essa orientação é de todo aplicável ao ambiente universitário. A autonomia da universidade é garantia constitucional máxima. Pétrea. Ela destina-se a impedir que o Estado substitua a própria universidade para indicar o que pode ou o que não pode ser debatido nesse ambiente. O que debater, como debater, quando debater são decisões que não estão sujeitas ao controle estatal prévio. Mais do que isso: a Constituição abomina qualquer intervenção que afaste o funcionamento do livre mercado de ideias, para lembrar a acepção utilizada por Oliver Holmes Jr. em Abrams v. United States.

19 Vide: Notícias do STF - Plenário anula decisões que proibiram atos com temática eleitoral nas universidades em 2018. Disponível em: http://www.stf.jus.br/portal/cms/verNoticiaDetalhe.asp?idConteudo=443456. Acesso em: 26 nov. 2020. 
Nas universidades e nas instituições de ensino, mais do que em qualquer outro lugar, as ideias disputam o coração das pessoas. Elas devem, portanto, livremente circular, para que a melhor possa prevalecer.

A universidade não tem parte para que todos tenhamos parte nela. A universidade é de todos. É pública na mais verdadeira essência do termo: é a realização da liberdade de pensamento a partir da interação com os outros, como a descrevia Hannah Arendt. Sob a proteção constitucional de liberdade de expressão agiganta-se a percepção que os docentes e discentes são livres para o exercício da cidadania e dos seus direitos políticos - que não se circunscrevem ao voto e passam necessariamente pelo debate de ideias, propostas e visões de mundo.

Por tudo isso, ações em universidades públicas que, a pretexto de garantir a aplicação da lei eleitoral, cerceiam, sem garantir o devido peso à liberdade de expressão, não podem ter o beneplácito no Estado democrático de Direito e reverberam negativamente para as instituições públicas e para a nossa democracia. Atingem o núcleo essencial dos preceitos fundamentais da Constituição e merecem ser afastadas por esta Corte. ${ }^{20}$

Esse precedente do Supremo Tribunal Federal assentou que "pluralismo não é unanimidade", de forma que "impedir a manifestação do diferente e à livre manifestação de todas as formas de apreender, aprender e manifestar a sua compreensão de mundo é algemar as liberdades, destruir o direito e exterminar a democracia”. E também registrou, nos anais da Suprema Corte brasileira, que "O pluralismo de ideias está na base da autonomia universitária como extensão do princípio fundante da democracia brasileira, que é exposta no inc. V do art. $1^{\circ}$ da Constituição da República". ${ }^{21}$

Se fundada na noção de direitos fundamentais, a democracia precisa encontrar mecanismos institucionais para diferenciar os direitos dos privilégios e das carências de um povo. Nesse contexto, ensina a professora Marilena Chauí:

(...) a cidadania se constitui pela e na criação de espaços sociais de lutas (movimentos sociais, movimentos populares, movimentos sindicais) e pela instituição de formas políticas de expressão permanente (partidos políticos, Estado de direito, políticas econômicas e sociais) que criem, reconheçam e garantam a igualdade e liberdade

20 STF/ADPF 548, Relatora Ministra Cármen Lúcia, Plenário, DJe 06.10.2020, voto do Ministro Edson Fachin, p. 82-83/240. Disponível em: http://portal.stf.jus.br/processos/downloadPeca.asp?id=15344606689\&ext=. pdf. Acesso em: 28 nov. 2020.

21 STF/ADPF 548, Relatora Ministra Cármen Lúcia, Plenário, DJe 06.10.2020, Ementa, p. 2/240. Disponível em: http://portal.stf.jus.br/processos/downloadPeca.asp?id=15344606689\&ext=.pdf. Acesso em: 28 nov. 2020. 
dos cidadãos, declaradas sob a forma dos direitos. Em outras palavras, desde a sua fundação, a democracia é inseparável da ideia de espaço público. Ou melhor, é com ela que nasce a ideia e a instituição do espaço público, à distância do espaço privado e da família, da economia e da religião. ${ }^{22}$

A universidade e a democracia, assim, constituem-se reciprocamente. Elas se impõem e se condicionam em uma relação dinâmica e multilateral, sempre como um esforço contínuo de garantirem os fundamentos básicos necessários à sustentação do Estado Democrático de Direito, e com e por ele, da própria Constituição.

\section{Universidade \& República}

República é significante não dotado de univocidade e pode ser um conceito pragmático, ${ }^{23}$ ou seja, nenhum tipo ideal a define ou a condiciona. É uma realidade em construção desde há muitos séculos e que continua a desafiar e a constranger as reflexões mais atuais sobre o Estado e a Constituição.

Com o auxílio da doutrina da professora Ana Paula de Barcellos, é preciso repetir que, não obstante a fluidez histórica e a constante ressignificação do termo, a República, como princípio institucional estruturante do constitucionalismo contemporâneo, conta com “(...) uma ideia essencial comum: trata-se da noção, de alguma forma associada à ideia de república, de restrição do poder absoluto, de governo justo e do exercício do poder político orientando para o bem da coletividade". ${ }^{24}$

A professora Rosah Russomano ensinava, no auge dos anos de chumbo, que a República se sublinha pela “(...) distinção dos poderes, pela qual as funções estatais são se concentram nas mãos de um só indivíduo ou de uma classe, sendo, pelo contrário, distribuídas por órgãos distintos, que se controlam mutuamente, evitando as demasias recíprocas, com o que se protegem, em última análise, as liberdades públicas". ${ }^{25}$

A República caracteriza-se como um ideal de apropriação do poder pelo seu verdadeiro soberano, o povo. Não obstante seja demasiado abstrato o conceito de povo como titular do poder, é preciso sempre relembrar que, no contexto do Estado Democrático de Direito brasileiro, fundado pelo constituinte de 1988, é do povo a

22 CHAUÍ, Marilena. Escritos sobre a universidade. São Paulo: Editora UNESP, 2001, p. 12-13.

23 Aqui a referência à semiótica é obrigatória. Pragmática, como uma das áreas da ciência dos signos significa que o conceito está informado também pelo seu contexto. Por todos vide: NORTH, Winfried; SANTAELLA, Lúcia. Introdução à Semiótica: passo a passo para compreender os signos e a significação. São Paulo: Paulus, 2017.

24 BARCELLOS, Ana Paula de. Curso de Direito Constitucional. Rio de Janeiro: Editora Forense, 2018 , p. 118-119.

25 RUSSOMANO, Rosah. Lições de Direito Constitucional. Rio de Janeiro: José Konfino Editor,1968, p. 181. 
decisão pela sua soberania perante o Estado-Nação. E, nesse ponto, preciosas as lições da Ministra Cármen Lúcia:

Ao contrário, pois, do que se poderia pensar num primeiro momento, a cidadania brasileira é extremamente forte: não o fosse, da República já não restaria sequer o nome constitucional, quanto mais o ideal que se faz mostrado, ainda que de forma pouco expressa, no plebiscito de 1993. O cidadão brasileiro é melhor do que seu governante. A cidadania melhor que o governo. A República, mais profunda que a corrupção, que teima em florescer feito planta daninha na administração da coisa pública. Ao cidadão o compromisso, o dever, a única esperança, prática republicana verdadeira e indiscutível, buscada pelos republicanos de 1889 e idealizada para os que vierem a sê-lo daqui a cem anos. ${ }^{26}$

A ideia de universidade associa-se, pois, ao ideal republicano de acesso universal à cidadania em seu sentido mais amplo. A universidade é um lugar de ensino do conhecimento universal, que, implica necessariamente a difusão e ampliação do conhecimento como o mais importante consectário da liberdade de expressão, de pensamento e da autodeterminação.

A universidade é um dos ambientes republicanos de acesso universal ao conhecimento e ciência, elementos necessários para a formação e informação do sujeito da contemporaneidade, de modo que, conforme adverte Boaventura de Sousa Santos:

(...) com a transformação da universidade num serviço a que se tem acesso, não por via da cidadania, mas por via do consumo e, portanto, mediante pagamento, o direito à educação sofreu uma erosão radical. A eliminação da gratuidade do ensino universitário e a substituição de bolsas de estudo por empréstimos foram os instrumentos da transformação dos estudantes de cidadãos em consumidores. $^{27}$

É marca da Constituição da República o repúdio veemente ao cerceamento da liberdade de expressão do pensamento. O texto constitucional não apenas consagra a liberdade no art. $5^{\circ}$ ("é livre a expressão da atividade intelectual, artística, científica e de comunicação, independentemente de censura ou licença"), como também, para que não reste dúvidas, no art. 206, quando o repete para a educação: “o ensino será ministrado

26 ROCHA, Cármen Lúcia Antunes. República e Federação: traços constitucionais da organização política brasileira. Belo Horizonte: Editora Del Rey, 1997, p. 86.

27 SANTOS, Boaventura de Sousa. A universidade no século XXI: para uma reforma democrática e emancipatória da Universidade, 3. ed. São Paulo: Editora Cortez, 2010, p. 27. 
com base (...) na liberdade de aprender, ensinar, pesquisar e divulgar o pensamento, a arte e o saber".

A liberdade de expressão, enquanto direito individual, é também complementada pelos tratados internacionais de direitos humanos. No Pacto de São José da Costa Rica e no Pacto de Direitos Civis e Políticos, por exemplo, ela é protegida nos seguintes termos, respectivamente:

Artigo 13. Liberdade de pensamento e de expressão

1. Toda pessoa tem direito à liberdade de pensamento e de expressão. Esse direito compreende a liberdade de buscar, receber e difundir informações e idéias de toda natureza, sem consideração de fronteiras, verbalmente ou por escrito, ou em forma impressa ou artística, ou por qualquer outro processo de sua escolha.

2. O exercício do direito previsto no inciso precedente não pode estar sujeito a censura prévia, mas a responsabilidades ulteriores, que devem ser expressamente fixadas pela lei e ser necessárias para assegurar:

a. o respeito aos direitos ou à reputação das demais pessoas; ou

b. a proteção da segurança nacional, da ordem pública, ou da saúde ou da moral públicas.

3. Não se pode restringir o direito de expressão por vias ou meios indiretos, tais como o abuso de controles oficiais ou particulares de papel de imprensa, de freqüências radioelétricas ou de equipamentos e aparelhos usados na difusão de informação, nem por quaisquer outros meios destinados a obstar a comunicação e a circulação de idéias e opiniões.

4. A lei pode submeter os espetáculos públicos a censura prévia, com o objetivo exclusivo de regular o acesso a eles, para proteção moral da infância e da adolescência, sem prejuízo do disposto no inciso 2.

5. A lei deve proibir toda propaganda a favor da guerra, bem como toda apologia ao ódio nacional, racial ou religioso que constitua incitação à discriminação, à hostilidade, ao crime ou à violência."

"Artigo 19.

1. Ninguém poderá ser molestado por suas opiniões.

2. Toda pessoa terá direito à liberdade de expressão; esse direito incluirá a liberdade de procurar, receber e difundir informações e idéias de qualquer natureza, independentemente de considerações de fronteiras, verbalmente ou por escrito, em forma impressa ou artística, ou por qualquer outro meio de sua escolha.

3. O exercício do direito previsto no parágrafo 2 do presente artigo implicará deveres e responsabilidades especiais. Conseqüentemente, poderá estar sujeito a certas restrições, 
que devem, entretanto, ser expressamente previstas em lei e que se façam necessárias para:

a) assegurar o respeito dos direitos e da reputação das demais pessoas;

b) proteger a segurança nacional, a ordem, a saúde ou a moral públicas.

A liberdade de cátedra, portanto, guarda uma especificidade em relação à liberdade do espaço público: é preciso que o ensino ministrado em sala de aula esteja em diálogo permanente e atual com a comunidade científica mais ampla. A fórmula para se chegar a esse resultado está na garantia, também constitucional, como não poderia deixar de ser, da autonomia universitária. Apenas a comunidade científica, integrada pelos pesquisadores das instituições de ensino, tem a competência para definir os conteúdos ministrados em aula e, neste ponto, é indevida, inconstitucional e antidemocrática a intervenção estatal. Noutras palavras, a definição do conteúdo ministrado pertence apenas à comunidade científica, jamais ao Estado.

Em decisão antológica, esta Suprema Corte, em 24 de agosto de 1964, enfrentou questão referente ao âmbito de proteção da liberdade de cátedra, concedendo a ordem no Habeas Corpus n. 40.910, Relator Ministro Hahnemann Guimarães, Tribunal Pleno, decisão unânime, numa situação em que foi decretada a prisão de um professor de economia da Universidade Católica de Pernambuco, com fundamento na Lei de Segurança Nacional. Conforme narrativa do Ministro Relator:

(...) a denúncia afirma que o paciente, no exercício da Cadeira de Introdução à Economia, distribuiu aos seus alunos um manifesto, com o fim de fazer propaganda de ódio de classe, conduta que está em consonância com as ideias comunistas do denunciado, o qual no exercício de sua Cadeira de professor, na Universidade Católica de Pernambuco, escreveu, em um pedaço de papel, dizeres subversivos, "Viva o Partido Comunista". No manifesto que se encontra por certidão a fls. 41 , o paciente faz crítica desfavorável à situação política atual, acentuando, afinal, que aos estudantes "cabe uma responsabilidade, uma parcela de decisão dos destinos da sociedade e para isto têm que optar entre 'gorilisar-se' ou permanecerem seres humanos. A estes cabe a honra de defender a democracia e a liberdade". ${ }^{28}$

Em seu relatório, o Ministro Hahnemann Guimarães afirmou que:

28 STF/HC 40.910, Relator Ministro Hahnemann Guimarães, Plenário, DJ 24.08.1964, p. 2-3/24. Disponível em: http://redir.stf.jus.br/paginadorpub/paginador.jsp?docTP=AC\&docID=57711. Acesso em: 25 nov. 2020 . 
o paciente exerceu as liberdades de pensamento e de cátedra, garantidas pela Constituição, artigos $141, \S 5^{\circ}$, e 168, VII. Professor da Faculdade de Ciências Econômicas da Universidade Católica de Pernambuco, o paciente distribuiu entre 26 alunos, que haviam comparecido à aula para prestação de provas, no dia 26 de Junho do corrente ano, um manifesto contrário à situação política vigente, sem nenhum incitamento à prática de processos violentos para a subversão da ordem política ou social, ou à desobediência coletiva ao cumprimento de lei de ordem pública. ${ }^{29}$

Seguiram, à unanimidade, todos os demais ministros integrantes da Corte. Em seu voto, o Ministro Evandro Lins, citando o livro "The Right of the People" do Juiz da Suprema Corte Americana William Douglas, afirmou a liberdade de expressão do pensamento como aquela que permite aos professores a busca de ideias em todos os domínios, sendo a Universidade uma espécie de contínua conversação socrática, de alto nível, “(...) com as melhores pessoas que se possa imaginar e reunir - sobre as mais importantes questões, e deve-se fazer o possível para garantir a tais homens a liberdade - de pensar e de expressar-se." ${ }^{30}$

Também o Ministro Victor Nunes pontuou a importância da liberdade de cátedra como um problema distinto da liberdade de pensamento em geral, afirmando, à época, que:

No Brasil, quase tudo está por se fazer. Nosso futuro depende do espírito de criação dos homens de pensamento, principalmente dos jovens, e não há criação, no mundo do espírito, sem liberdade de pensar, de pesquisar, de ensinar. Se há um lugar em que o pensamento deve ser o mais livre, este lugar é a universidade, que é o laboratório do conhecimento. E eu não gostaria que os jovens brasileiros pudessem, algum dia, reproduzir, ao pé da letra, aquelas palavras melancólicas de Einstein, ou pudessem comparar a nossa universidade com as universidades dos países submetidos à ditadura. ${ }^{31}$

E continua, como conclusão de seu voto, o Ministro Victor Nunes:

29 STF/HC 40.910, Relator Ministro Hahnemann Guimarães, Plenário, DJ 24.08.1964, p. 2-24. Disponível em: http://redir.stf.jus.br/paginadorpub/paginador.jsp?docTP=AC\&docID=57711. Acesso em: 25 nov. 2020.

30 STF/HC 40.910, Relator Ministro Hahnemann Guimarães, Plenário, DJ 24.08.1964, p. 7-24. Disponível em: http://redir.stf.jus.br/paginadorpub/paginador.jsp?docTP=AC\&docID=57711. Acesso em: 25 nov. 2020.

31 STF/HC 40.910, Relator Ministro Hahnemann Guimarães, Plenário, DJ 24.08.1964, p. 16-17/24. Disponível em: http://redir.stf.jus.br/paginadorpub/paginador.jsp?docTP=AC\&docID=57711. Acesso em: 25 nov. 2020 . 
(...) tudo isso deve ser resolvido no âmbito da universidade. Os riscos da liberdade do pensamento universitário são altamente compensados com os benefícios que a universidade livre proporciona ao povo, ao desenvolvimento econômico do País, ao aperfeiçoamento moral e intelectual da humanidade. E assim quer a Constituição, porque, além de consagrar a liberdade de pensamento em geral, também garantiu, redundantemente, a liberdade de cátedra (art. 168, VII). Concedo a ordem. ${ }^{32}$

Tais premissas dogmáticas conduziram às razões de conhecimento e provimento da Ação Direta de Inconstitucionalidade n. 5537, Relator o Ministro Luis Roberto Barroso, Plenário, DJe 17.09.2020, cuja ementa, na parte que diz respeito à intrínseca e importante relação entre universidade e república, como formas de acesso amplo e universal ao conhecimento, ao poder de autodeterminação e à atuação no espaço público livre de preconceitos, de condicionantes de ordem moral ou religiosa, ou de parâmetros previamente estabelecidos por quaisquer autoridades do Estado. Assim foi publicada a ementa do referido julgado:

\section{(...)}

5. Violação do direito à educação com o alcance pleno e emancipatório que lhe confere a Constituição. Supressão de domínios inteiros do saber do universo escolar. Incompatibilidade entre o suposto dever de neutralidade, previsto na lei, e os princípios constitucionais da liberdade de ensinar, de aprender e do pluralismo de ideias (CF/1988, arts. 205, 206 e 214).

6. Vedações genéricas de conduta que, a pretexto de evitarem a doutrinação de alunos, podem gerar a perseguição de professores que não compartilhem das visões dominantes. Risco de aplicação seletiva da lei, para fins persecutórios. Violação ao princípio da proporcionalidade (CF/1988, art. $5^{\circ}, \mathrm{LIV}, \mathrm{c} / \mathrm{c}$ art. $\left.1^{\circ}\right) .^{33}$

Em uma República, a Constituição é a lei do cidadão, ${ }^{34}$ e o cidadão coletivamente constituinte e constituído é o povo soberano detentor de todo o poder do Estado. Se não há um consenso sobre os objetivos da Universidade, uma das correntes

32 STF/HC 40.910, Relator Ministro Hahnemann Guimarães, Plenário, DJ 24.08.1964, p. 20-24. Disponível em: http://redir.stf.jus.br/paginadorpub/paginador.jsp?docTP=AC\&docID=57711. Acesso em: 25 nov. 2020.

33 STF/ADI 5537, Relator Ministro Luis Roberto Barroso, Plenário, DJe 17.09.2020, p. 1-47. Disponível em: http://redir.stf.jus.br/paginadorpub/paginador.jsp?docTP=TP\&docID=753837203. Acesso em: 25 nov. 2020.

34 Essa afirmação é da Ministra Cármen Lúcia: "A Constituição é lei do cidadão, não é de governantes”. Disponível em: https://www.jota.info/paywall?redirect_to=//www.jota.info/stf/do-supremo/carmen-luciaa-constituicao-e-lei-do-cidadao-nao-e-de-governantes-29102020. Acesso em: 25 nov. 2020. 
em disputa merece especial atenção pelo seu intrínseco compromisso com o princípio republicano: a que defende a responsabilidade social das universidades. Alerta-nos o professor Boaventura de Sousa Santos:

(...) a concepção mais ampla de responsabilidade social, de participação na valorização das comunidades e de intervenção reformista nos problemas sociais continua vigente no imaginário simbólico de muitas universidades e de muitos universitários e tende a reforçar-se em períodos históricos de transição ou de aprofundamento democráticos. ${ }^{35}$

Assim, a liberdade de expressão e de pensamento na educação devem ser norteadoras de toda a atividade que envolve o conhecimento e a informação dos cidadãos e das cidadãs, especialmente porque os estudantes, de todos os níveis de ensino, estão no caminho de escolhas intrínseco a seus processos formativos. Abre-se, pois, o caminho para se discutir a autonomia universitária.

\title{
5. Universidade \& Autonomia
}

A crise das universidades, por tudo que já foi aqui exposto, também se confunde com a crise das constituições, das democracias e das repúblicas. São diversos e complexos os fatores que constrangem e ameaçam a hegemonia, a legitimidade e a institucionalidade das universidades, tanto no Brasil, quanto no mundo.

A crise de hegemonia ocorre sempre que uma determinada condição social deixa de ser considerada necessária, imprescindível e exclusiva. Nesse particular, a crise da ideia de universidade resulta das dificuldades de tais instituições conseguirem atender com eficiência a todas as suas funções. ${ }^{36}$ Relembra Boaventura de Sousa Santos:

\begin{abstract}
A exigência posta no trabalho universitário, a excelência dos seus produtos culturais e científicos a criatividade da atividade intelectual, a liberdade e discussão, o espírito crítico a autonomia e o universalismo dos objetivos fizeram da universidade uma instituição única, relativamente isolada das restantes instituições sociais, dotada de grande prestígio social e considerada imprescindível para a formação das elites. ${ }^{37}$
\end{abstract}

35 SANTOS, Boaventura de Sousa. Da ideia de Universidade à Universidade de ideias. Revista Crítica de Ciências Sociais, v. 27, n. 28, 1989, p. 35.

36 SANTOS, Boaventura de Sousa. Da ideia de Universidade à Universidade de ideias. Revista Crítica de Ciências Sociais, v. 27, n. 28, 1989, p. 14-15.

37 Idem, ibidem. 
A crise de legitimidade é caracterizada quando uma dada condição social deixa de ser aceita como consenso, e no caso das universidades, a crise de instala e se torna cada vez mais irreversível quando se torna indiscutível o colapso dos objetivos coletivamente assumidos pelos atores do processo de educação em nível superior. ${ }^{38}$ Por fim, a crise institucional opera-se na circunstância em que a sua especificidade organizativa é questionada, sendo a ela impostos outros modelos organizativos com maior sucesso em outras instituições. ${ }^{39}$

Há, portanto, três núcleos que compõem indissociavelmente a autonomia universitária, sendo eles, em primeiro lugar, a liberdade de definição de seus próprios critérios de funcionamento científico; em segundo lugar, sua autorregulação administrativa; e, em terceiro lugar, a garantia de independência financeiro-patrimonial. ${ }^{40}$

O Supremo Tribunal Federal foi instado a contribuir para esse debate, em virtude do ajuizamento da ADI 6565, ainda pendente de julgamento pelo Plenário. Uma vez mais, esta ação conclama a Suprema Corte brasileira a debater a autonomia universitária, princípio basilar da garantia institucional firmada pelo constituinte de 1988, quanto à educação de nível superior do Brasil.

O protagonismo das universidades não apenas para a (con)formação de uma sociedade de cidadãos e cidadãs livres e iguais, mas, também, sua responsabilidade para com a cidadania, como valor social forjado em um ambiente verdadeiramente (in)formado pela pluralidade de ideias e pela transparência das pesquisas científicas, foram as premissas para a compreensão externada por ocasião do julgamento da medida cautelar, na ADI 6565:

(...) a autonomia universitária albergada pela Constituição de 1988 é sensivelmente distinta daquela encampada pelo ordenamento jurídico brasileiro até então.

É interessante notar, de início, que já no Anteprojeto Constitucional, elaborado pela Subcomissão da Educação, Cultura e Esportes, ficava claro não apenas que o princípio da autonomia universitária deveria ter assento constitucional, mas também que deveriam ser tomadas as medidas técnicas necessárias para que a legislação ordinária viesse a tolher sua amplitude. Leia-se, a este respeito, o art. $8^{\circ}$ do Anteprojeto:

"Art. $8^{\circ}$. As universidades e demais instituições de ensino superior gozam, nos termos da lei, de autonomia didático-científica, administrativa e financeira, obedecidos seguintes princípios:

Idem, ibidem, p. 15.

Idem, ibidem.

40 STF/ADI 6565, Relator Ministro Edson Fachin, voto proferido no plenário virtual em 09.10.2020. 
I - indissociabilidade do ensino, pesquisa e extensão;

II - padrão unitário comum de qualidade, indispensável para que cumpram seu papel de agente da soberania cultural científica, artística e tecnológica do país;

III - gestão democrática através de critérios públicos e transparentes, com participação de docentes, alunos e funcionários e representantes da comunidade na escolha dos dirigentes" (Grifos meus).

As exigências de democratização atreladas ao princípio da autonomia universitária fazem ver uma diferença que é traçada em relação à compreensão anterior deste conceito. Ainda que o supracitado inciso III tenha sido retirado das propostas aprovadas subsequentemente na Comissão temáticas da Família, da Educação, Cultura e Esportes, da Ciência e Tecnologia e da Comunicação, e que tenha havido um debate inconcluso a respeito das eleições internas para cargos de direção (cf., a título de exemplo, Emenda 06010, Fase M, autor Álvaro Valle, Comissão de Sistematização), as discussões do plenário da Assembleia Nacional Constituinte conduziram a uma reafirmação da dimensão constitucional tanto do princípio da autonomia universitária, quanto do princípio da gestão democrática do ensino público. Este último permanece disposto no inciso VI do art. 206 da CRFB/88: “Art. 206. O ensino será ministrado com base nos seguintes princípios: VI - gestão democrática do ensino público, na forma da lei".

$\mathrm{O}$ art. 207 ficou assim redigido: "Art. 207. As universidades gozam de autonomia didático-científica, administrativa e de gestão financeira e patrimonial, e obedecerão ao princípio de indissociabilidade entre ensino, pesquisa e extensão".

Cumpre notar, quanto ao princípio da autonomia universitária, que também sua formulação textual restou modificada em relação às subsequentes redações anteriores, nomeadamente aquela da Lei Federal $\mathrm{n}^{\circ}$ 5.540/68 que, permito-me citá-la uma vez mais para fins de comparação, estabelecia: "Art. $3^{\circ}$ As universidades gozarão de autonomia didático-científica, disciplinar, administrativa e financeira, que será exercida na forma da lei e dos seus estatutos" (Grifos meus).

Esta conjunção entre mudança de estatura normativa e construção redacional não escapou ao olhar dos principais especialistas do tema na literatura jurídica, que enxergaram no art. 207 a inscrição de uma norma de eficácia plena e de aplicabilidade imediata. Colha-se a lição do professor Almiro do Couto e Silva:

"Na verdade, ao princípio acolhido no seu art. 207 o nosso Estatuto Político Fundamental não apôs qualquer cláusula restritiva, do tipo 'na forma da lei', à semelhança 
do art. 33 da Constituição Italiana, de modo a fazer do preceito constitucional uma regra de eficácia contida, na classificação de José Afonso da Silva, que tão merecido prestígio conquistou no Direito Brasileiro ('Aplicabilidade das" Normas Constitucionais', São Paulo, RT, 1968). Cogita-se por consequência, de uma norma de eficácia plena, insuscetível de ter o seu significado e sua extensão diminuídos, ainda que em mínima parte, pela legislação ordinária. Não é que a regra constitucional vede legislação ordinária que lhe explicite, de forma mais minuciosa ou pormenorizada seu sentido, facilitando-lhe a aplicação às situações concretas. O que a norma constitucional sobre autonomia universitária impede terminantemente é que a legislação ordinária, sob pretexto de dar tratamento mais minudente ao preceito superior, acabe por desvirtuá-lo, conferindo-lhe um contorno e uma dimensão que ele não possui” (COUTO E SILVA, A. apud GUERRA, W. S. A questão da Autonomia Universitária. Revista da Fac. de Direito, v. 31/2, p. 113-114, 1990-91).

Neste sentido, o não menos valioso magistério da professora Anna Cândida da Cunha Ferraz, que conclui de forma incisiva:

"De outro lado, a inserção constitucional da autonomia universitária na obra do constituinte originário traz como conseqüência a sua intangibilidade por normas de hierarquia inferior: leis federais, leis estaduais e municipais, ou mesmo as Constituições dos Estados (ainda que obras de um poder constituinte estadual autônomo por força do princípio federativo que preside a organização do Estado no Brasil). Inscrito na Constituição Federal, o princípio da autonomia universitária tem uma dimensão fundamentadora, integrativa, diretiva e limitativa própria, o que significa dizer que é na própria Constituição Federal: a) que se radica o fundamento do instituto; b) que é dela que se extrai sua força integrativa em todo o sistema federativo do País; c) que a Constituição Federal preordena a interpretação que se possa dar ao instituto; d) que os limites que se podem opor à autonomia universitária têm como sede única a própria Constituição Federal; e) que o princípio da autonomia universitária, como princípio constitucional, deve ser interpretado em harmonia - mas no mesmo nível - com os demais princípios constitucionais" (FERRAZ, Anna Cândida Da Cunha. A autonomia universitária na Constituição de 05.10.1988. R. Dir. Adm, n. 215, p. 117142, 1999, p. 123).

Em outras palavras, além de sua elevação ao rol constitucional, o Constituinte cristaliza a autonomia universitária em norma de eficácia plena e de aplicabilidade imediata, que só poderá ser limitada 
por outra norma de igual estatura. Evidencia-se, assim, a meu sentir, que a instanciação existencial da norma da autonomia pressupõe a premissa válida de que, no sistema constitucional de 1988, não se está simplesmente dando assento superior a este princípio, mas sim reformulando-o completamente em relação à normatividade autoritária precedente (cf., a este propósito, CIRNE, Mariana; e PAIXÃO, Cristiano. História constitucional do princípio da autonomia universitária no Supremo Tribunal Federal. Rev. Fac. Dir. UFPR, v. 63, n. 3, 2018, p. 105 - 133).

E, para arrematar as inquietações sobre tema ainda tão vivo e pujante para o presente e o futuro das universidades no Brasil, reproduzo aqui, uma vez mais, ${ }^{41}$ as lições da professora Nina Ranieri, vindas a público pela editora da Universidade de São Paulo, sobre o sentido do termo autonomia:

Os juristas, entretanto, nunca lhe designaram valor jurídico preciso (em virtude de sua própria formulação política, como se verá), de sorte que o termo "autonomia" é indistintamente associado a situações, sujeito, fatos e atos. Ademais, conquanto de modo geral exprima "poder de autonormação" (sendo este seu significado primordial e, de acordo com a maioria dos doutrinadores, o único autêntico em sede jurídica), o vocábulo é também usado para qualificar atos administrativos (quando, em relação aos atos anteriores e posteriores, não formam procedimentos); para designar órgãos com poder de ação independentes; para indicar independência financeira (autonomia financeira); para denotar liberdade de julgamento (autonomia valorativa); autodeterminação (autonomia da vontade) e, ainda, autogoverno, autoadministração, etc. ${ }^{42}$

Não se pode pensar em Constituição, Democracia, República e Universidade sem a compreensão do sentido de autonomia, porquanto somente pela autonomia, institucional e pessoal, é possível vislumbrar que o caminho está trilhado, e que a fumaça dos tempos sombrios já se esvai compelida pelo sopro poderoso daqueles que acreditam no Estado Democrático de Direito.

41 Essa citação também está presente no voto que proferi por ocasião do julgamento da cautelar na ADI 6565, Relator Ministro Edson Fachin, julgamento ainda pendente de conclusão no Plenário do Supremo Tribunal Federal. Andamento processual disponível em: http://portal.stf.jus.br/processos/detalhe. asp?incidente $=6009885$. Acesso em: 28 nov. 2020 .

42 RANIERI, Nina. Autonomia universitária: as universidades públicas e a Constituição Federal de 1988. São Paulo: Editora da USP, 1994. 


\section{Universidade e Igualdade}

E não há também nação democrática sem acesso amplo, múltiplo, diverso e igualitário à universidade. Estudantes-cidadãos podem ser todos e todas, e essa afirmação numa sociedade diversa e desigual como a nossa, só pode ocorrer a partir do reconhecimento dessas diferenças e desigualdades e da garantia do acesso àqueles que foram historicamente alijados.

É isso o que colhemos, por exemplo, das cotas raciais. Sobre o tema, cabe retomar trecho do julgamento da ADPF 186, pelo Supremo Tribunal Federal, em 2012:

Não contraria - ao contrário, prestigia - o princípio da igualdade material, previsto no caput do art. $5^{\circ}$ da Carta da República, a possibilidade de o Estado lançar mão seja de políticas de cunho universalista, que abrangem um número indeterminados de indivíduos, mediante ações de natureza estrutural, seja de ações afirmativas, que atingem grupos sociais determinados, de maneira pontual, atribuindo a estes certas vantagens, por um tempo limitado, de modo a permitir-lhes a superação de desigualdades decorrentes de situações históricas particulares. ${ }^{43}$

É dizer, a igualdade não se esgota com a previsão normativa de acesso igualitário a bens jurídicos, mas engloba também a previsão normativa de medidas que efetivamente possibilitem tal acesso e sua efetivação concreta. Sueli Carneiro pontifica:

O princípio que orienta a adoção de políticas de ação afirmativas e um de seus instrumentos, as cotas, baseiase num imperativo ético e moral de reconhecimento das desvantagens historicamente acumuladas pelos grupos discriminados em dada sociedade, que sustentam os privilégios de que desfrutam os grupos raciais dominantes e explicam as desigualdades de que padecem os dominados. ${ }^{44}$

Tais ações, no âmbito das universidades, tem gerado impactos positivos de diversas ordens. Não apenas na construção de conhecimento crítico, mas também como elemento para transformação social. É o que podemos extrair, por exemplo, de pesquisas elaboradas sobre as trajetórias de estudantes cotistas negros:

Percebemos, ainda, no conjunto das entrevistas, que aqueles estudantes ingressantes por meio de cotas e que desenvolveram, ou intensificaram, a percepção de sua identidade racial, ao longo da vida universitária, relatam

\footnotetext{
43 ADPF 186, Relator: RICARDO LEWANDOWSKI, Tribunal Pleno, julgado em 26/04/2012, ACÓRDÃO ELETRÔNICO DJe-205, divulg. 17-10-2014, public. 20-10-2014 RTJ VOL-00230-01 PP-00009.

44 CARNEIRO, Sueli. Racismo, sexismo e desigualdade no Brasil. São Paulo: Selo Negro, 2011. p. 105.
} 
um posicionamento mais crítico em relação aos modos de organização das universidades brasileiras, de seus currículos, de seus modos de avaliação e reconhecimento de mérito acadêmico. Constroem-se, dessa forma, não apenas como alunos universitários, mas como intelectuais engajados na produção do conhecimento e na luta antirracista. $^{45}$

A pluralidade de ideias enriquece o debate, o diálogo e viabiliza a verdadeira construção dos saberes.

\section{Ideias de arremate}

Se as perguntas mais frequentes são razoavelmente estáveis resumindo-se, de um lado, a buscar questionar o papel das universidades nas sociedades contemporâneas, e de outro lado, a encontrar caminhos sustentáveis para aproximar a universidade dos cidadãos e cidadãs de uma nação, as respostas para estas perguntas ainda são voláteis.

O caminho escolhido e percorrido pelos autores do presente trabalho uniu Constituição e Universidade como garantias institucionais de múltiplos direitos fundamentais dos sujeitos e protagonistas de suas histórias como povo e nação autônomos.

As premissas de que as crises enfrentadas pela Constituição são também sentidas pela Universidade, e vice-versa, partiram do pressuposto de que a (con) formação desse povo passa necessariamente pela in(formação) em todas as suas mais amplas perspectivas.

Uma nação democrática pressupõe universidades livres, estudantescidadãos que gozem dos seus direitos fundamentais de liberdade, sociais e políticos, na sua máxima potencialidade. E, somente é possível afirmar-se que uma nação é republicana, se (e quando) a liberdade de expressão, pensamento e autodeterminação estiverem incondicionalmente presentes no seio de suas instituições, especialmente nas universidades.

Por fim, a autonomia universitária é a resposta do constituinte de 1988 aos períodos de exceção democrática já experimentados algumas vezes pelo povo brasileiro. Dela não se pode descuidar, e toda a atenção deve-lhe ser dirigida pois as fórmulas de suas violações são sofisticadas e nem sempre facilmente perceptíveis.

Em tempos outros, as violações perpetradas contra a Universidade e contra a comunidade universitária não se davam malgrado a autonomia universitária. Não se tratava, frise-se, de atos simplesmente contra legem ou in fraudem legis, mas

45 JESUS, Rodrigo Ednilson (org.). Reafirmando direitos: trajetórias de estudantes cotistas negros (as) no ensino superior brasileiro. Belo Horizonte: Ações Afirmativas no Ensino Superior, 2019. p. 282. 
de manifestações da própria compreensão dominante da noção de autonomia, que ainda refletia uma visão de mundo autoritária e centralizadora. ${ }^{46}$

\section{E duas palavras sobre a pós-graduação em Direito no Brasil no tempo corrente}

Dentro desse contexto das universidades e do ensino superior, encerremos com duas palavras de singela reflexão sobre a pós-graduação, ambiente emoldurado por excelência com pesquisa e produção científica.

O contexto do tripé vincado por autonomia, democracia e república, vem à reflexão no ensejo da celebração dos 50 anos do Programa de Pós-Graduação da Faculdade de Direito da Universidade de São Paulo, meritoriamente -repisamos- uma bem-sucedida história institucional. Uma palavra impende, no ensejo, exarar sobre um dos singelos horizontes que pode estar na própria seara da pós-graduação em Direito no Brasil.

A pós-graduação em Direito, em seus níveis de mestrado e doutorado, experimentou nas últimas três décadas patamares exuberantes de forma e de conteúdo. Expansão vertical e ampliação horizontal projetou na pós-graduação stricto sensu expressões de respeito acadêmico, dentro e fora do País, bem como benfazeja ufania nos eleitos a habitar programas, curso, eventos, bancas examinadoras, premiações, intercâmbio e períodos sabáticos. Nada obstante, esse cenário modelar deve ser desafiado por uma pergunta que o latim elementar formula de modelo singelo: Cui prodest?

Tome-se como ponte metodológica a racionalidade que inspirou o sociólogo Jessé Souza na obra $A$ elite do atraso, ${ }^{47}$ um livro (como se anuncia na legítima e meritória provocação constante da orelha da contracapa) "para ser apoiado, debatido ou questionado". Será impossível reagir de maneira indiferente à leitura contundente de Jessé Souza aos nossos cânones acadêmicos e midiáticos". Nele propõe que "voltemos a praticar a reflexão autônoma que é a chave de tudo o que a raça humana produziu de bonito e de distinto na vida da espécie", e segundo o autor "a esperança de hoje tem que ser uma adaptação contemporânea do velho chamado aos explorados". ${ }^{48}$

Em outros termos, considerando o cenário crepuscular, a recessão democrática, a intolerância, a exclusão social e econômica, um mundo parasitário a caminho da dizimação do hospedeiro, é possível e quiçá necessário abismar-se sobre o que tem sido o impacto real, efetivo e concreto de três décadas de pujança da pósgraduação em Direito no Brasil como motor de transformação concreta da realidade.

\footnotetext{
46 ADI 6565, voto na cautelar proferido pelo Relator Ministro Edson Fachin, julgamento ainda pendente de conclusão no Plenário do Supremo Tribunal Federal. Andamento processual disponível em: http://portal. stf.jus.br/processos/detalhe.asp?incidente=6009885. Acesso em: 28 nov. 2020.

47 SOUZA, Jessé. A elite do atraso: da escravidão à Lava Jato. Rio de Janeiro: Leya, 2017.

48 Ob. cit., p. 234.
} 
Mutatis mutandis, sem tomar para análise todas as bases da reflexão que Jessé Souza faz sobre o patrimonialismo brasileiro, especialmente na distinção que intenta apresentar entre 'a corrupção real' e 'a corrupção dos tolos', é possível, com a devida licença, reconhecer que o sociólogo propicia uma importante interrogação que metodologicamente pode ser transporta à seara aqui em cena, a universidade, a própria pós-graduação em Direito, enfim a teoria e a prática acadêmica na produção científica.

Por essa via, haurindo apenas (e tão somente) essa nervura de método expositivo, aqui também cumpre indagar, décadas após a primavera da pós-graduação, inaugurada logo em seguida à vigência da Constituição de 1988, se o ambiente livre e competitivo das ideias na pós-graduação se fez inclusivo e emancipador. Mais ainda: como autorreflexão, impende interrogar o senso comum acadêmico (como o faz, à luz de suas premissas próprias, o reconhecido professor Jessé Souza) sobre a maioria esquecida, a crítica à desigualdade, a injustiça social, a fim de não naturalizar as colonizações de nomes e conceitos, obstando a capilaridade do discurso jurídico com o embate dos fatos sociais, culturais, históricos, políticos e econômicos do Brasil?

Guardadas todas as proporções e diferenças de amplitude, textos e contextos, se se tomar (como hipótese, sem a ela anuir de todo, a partir da relevante obra antes mencionada) a formação de uma elite do atraso, explicitada por meio da releitura do homem cordial de Sérgio Buarque de Holanda, dos donos do poder de Raymundo Faoro, parcialmente criticados e reconstruídos por Jessé Souza, assim também o fazendo com Gilberto Freyre e inclusive Florestan Fernandes, parece possível perguntar, por alguma analogia quiçá legítima, em que medida o pensamento jurídico contemporâneo produzida na (e pela) pós-graduação em Direito no Brasil tem sido mesmo transformador ou substancialmente reprodutor das condições materiais da vida injustas, excludentes e discriminatórias?

Inexiste resposta genérica às questões também generalizantes. Trata-se de uma formulação interrogativa retórica posta feito imagem especular diante do sujeito do autoconhecimento ${ }^{49}$ e daquilo que gera saudável desconforto. Pensar por problemas, como afirmamos ao início. A genuína dúvida desequilibra, a controvérsia aguda desloca e o dialogo incômodo constrói. Deslocar-se da zona de conforto, acolher o desassossego, reagir com acolhimento do desagradável, entender os limites e as possibilidades do que é diverso.

Ao menos no campo da metodologia do Direito Civil Constitucional e da teoria crítica do Direito Civil, assentado em dogmática crítica e refinada, tem sido feito

49 "O que o meu semelhante quer realmente me dizer? Isso equivale ao procedimento de um bom cientista, criminalista ou juiz, que não pronuncia uma sentença antes de conhecer os detalhes do caso". MÜLLER, Lutz. O herói: a verdadeira do herói e o caminho da individuação. 2. ed. São Paulo: Cultrix, 2017. p. 68. 
enorme esforço de trazer à tona aquilo que ainda está soterrado na produção da vida, sem os escudos que reproduzem sociedade e Estado, proclamados como democráticos, abertos e plurais, mas que ao fim e ao cabo legitimam um escudo impermeável de exclusão e injustiça.

Os fatos recentes enevoados desafiam a todos, especialmente para que o porvir não seja apenas o futuro do pretérito. Não existimos indiferentemente. Seres humanos somos, nessa complexidade sintetizada em duas expressões: ser-no-mundo, sendo com-os-outros.

É tempo de resiliência com o projeto de esperança costurado pela Assembleia Nacional Constituinte de 1987/88, pois que a consolidação de uma sociedade livre, justa, republicana e democrática ainda está em andamento, e para que possa ser sustentável, a partir da dinâmica e plurifacetada sociedade de nossos dias. Cumpre, enfim, responder sobre o mainstream da barbárie que se avizinha: cui prodest?

O presente é de perseverança e ação, de ideal e políticas públicas, de homens e mulheres de todos os gêneros imbuídos pelo espírito democrático, republicano e cidadão. Que o século XXI seja a memorabilia da maioria esquecida, e da realização dos compromissos constitucionais quanto à prevalência dos direitos humanos; da autodeterminação dos povos; da não-intervenção; da defesa da paz; da solução pacífica dos conflitos; do repúdio ao terrorismo e ao racismo; da cooperação entre os povos para o progresso da humanidade; e da integração econômica, política, social e cultural dos povos. A Universidade tem mesmo função constitucional a cumprir, e pode fazê-lo desde que assegurada plena autonomia.

\section{Referências}

BARCELlOS, Ana Paula de. Curso de Direito Constitucional. Rio de Janeiro: Editora Forense, 2018, p. 118-119.

BITTAR, Eduardo C.B., Democracia, Justiça e Direitos Humanos - estudos de teoria crítica e filosofia do direito. São Paulo: Saraiva, 2011, p. 49-51.

CARNEIRO, Sueli. Racismo, sexismo e desigualdade no Brasil. São Paulo: Selo Negro, 2011.

CHAUÍ, Marilena. Escritos sobre a universidade. São Paulo: Editora UNESP, 2001.

FACHIN, Luiz Edson; SILVA, Christine Peter da. Democracia representativa no Brasil: breves reflexões sobre a participação do povo como sujeito político. In: PEREIRA, Erick Wilson (org.). Reforma política: Brasil república: em homenagem ao Ministro Celso de Mello. Brasília, DF: OAB, Conselho Federal, 2017, p. 115-130.

JESUS, Rodrigo Ednilson (org.). Reafirmando direitos: trajetórias de estudantes cotistas negros (as) no ensino superior brasileiro. Belo Horizonte: Ações Afirmativas no Ensino Superior, 2019. 
MÜLLER, Lutz. O herói: a verdadeira do herói e o caminho da individuação. 2. ed. São Paulo: Cultrix, 2017.

NORTH, Winfried; SANTAELLA, Lúcia. Introdução à Semiótica: passo a passo para compreender os signos e a significação. São Paulo: Paulus, 2017.

RANIERI, Nina. Autonomia universitária: as universidades públicas e a Constituição Federal de 1988. São Paulo: Editora da USP, 1994.

ROCHA, Cármen Lúcia Antunes. República e Federação: traços constitucionais da organização política brasileira. Belo Horizonte: Editora Del Rey, 1997.

RUSSOMANO, Rosah. Lições de Direito Constitucional. Rio de Janeiro: José Konfino Editor,1968.

SANTOS, Boaventura de Sousa. A universidade no século XXI: para uma reforma democrática e emancipatória da Universidade, 3. ed. São Paulo: Editora Cortez, 2010.

SANTOS, Boaventura de Sousa. Da ideia de Universidade à Universidade de ideias, Revista Crítica de Ciências Sociais, v. 27, n. 28, 1989.

SANTOS, Richard. Maioria minorizada: um dispositivo da racionalidade. Rio de Janeiro: Telha, 2020 .

SARAMAGO, José. Democracia e Universidade. Belém/PA: Editora UFPA - Fundação José Saramago, 2013.

SOUZA, Jessé. A elite do atraso: da escravidão à Lava Jato. Rio de Janeiro: Leya, 2017. 